\title{
Agro-ecological and biological aspects of the components selection for mixed sowings of forage crops
}

\author{
S. Poltoretskyi ${ }^{1}$, V. Prykhodko ${ }^{1}$, N. Poltoretska ${ }^{1}$, E. Prokopenko ${ }^{1}$, H. Demydas ${ }^{2}$ \\ ${ }^{1}$ Uman National University of Horticulture (Uman), Cherkasy region, Uman, st. Instytutska, 1-20305, Ukraine. \\ ${ }^{2}$ National University of Life and Environmental Sciences of Ukraine (Kiev), st. Heroiv Oborony, 15-03041, Ukraine. \\ E-mail:poltorec@gmail.com \\ Received: 12.06.2019. Accepted: 08.07.2019
}

\begin{abstract}
Analytical review of domestic and foreign literary sources concerning ecological-and-biological features of the components choosing of mixed corn sowings with high-protein crops for the formation of the highest yields of high-qualitative fodders is given. As a result of the conducted analysis it was found that scientists do not have a common opinion regarding the optimal variety composition of the mixtures when growing for forage. However, the mixed sowings of corn with high-protein components compared with single-crop sowings can provide higher yields of herbage and getting of digestible protein. At the same time, compatible sowing contributes to the improvement of growth processes of all crops under optimizing of water and nutrient soil regimes, light and temperature conditions and photosynthesis processes by above-ground mass of plants.
\end{abstract}

Keywords: Corn; high-protein crops; single-crop and mixed sowing; yield; fodder quality; digestible protein; fodder unit

\section{Introduction}

The main task of the plant growing field and its accompanying fodder production is the production of fodders in the required amount for the uninterrupted provision of livestock production by high qualitative, cheap fodders and, above all, balanced by protein.

Unfortunately, the stock of cattle has decreased by 2.7 times in the past few years. Deficit of digestible protein in animal rations is $25 \%$, which leads to fodder over-consumption by 1.3-1.4 times and products shortage by $30-34 \%$, and, in turn, to the increase in products price by 2.5 .

One can solve these problems by using mixed sowings of corn with high-protein components.

Corn is one of the most common fodder crops, there is a lot of carbohydrates in its herbage and silage, but low protein (60-75 grams per fodder unit), which is lower than zootechnical standards (100-110 g).

It can be used one of the cheapest methods to enrich corn herbage and silage for protein compounds by using its mixed sowings with high-protein crops. The value of the mixed sowings is that they allow improving fodder quality, increasing the area of sowings assimilation, reducing the loss of solar energy, using moisture and nutrients in a more productive way.

However, the lack of knowing the peculiarities of yeild formation, depending on the selection of high-protein components and methods of sowing, leads to the deterrence of the expansion of areas under mixed sowings of corn while growing for silage.

Therefore, researches in this area are topical, since they provide the opportunity to develop and substantiate measures to improve the quality and increase the productivity of mixed sowings of corn with high-protein components.

The purpose of the study is to substantiate theoretically and determine the optimal variety composition of corn mixes with high-protein crops for fodder in specific soil-and-climatic conditions.

\section{Materials and Methods}

General scientific methods, in particular, such as: hypothesis, observation, analysis, synthesis, induction and deduction, abstraction and generalization were used during performing the study. Own observations and literary sources on the chosen sphere of the research were the material basis.

\section{Results and Discussion}

It is important to select the components properly when growing corn for fodder in the compatible sowings for the purpose to obtain high yields of herbage with increased protein content (Bondarev, 1996). 
The following legumes for simultaneous growing with corn for silage are selected which enter the phase of full beans development at the time of milk-waxy and waxy ripeness of corn grains, their leaves still remain green, and the stems are succulent (Allabardin, 1997). Its mixed sowings with soybean deserve the greatest attention among numerous possible combinations of corn growth together with grain legumes. This crop, like corn, belongs to the plants of short light day and late term of sowing, and their seedlings appear at the same time under compatible sowing. Also, both crops have close periods of slow and intensive growth, and under correct selection of the components at the time of panicle heading by corn plants, soybeans enter into the phase of mass flowering, and into the phase of the beginning of beans yellowing of the lower layer during the period of milk-waxy and waxy ripeness of corn grains.

Good components for growing in the mixed sowings with corn are supposed to be fodder bean. The yield of herbage of such sowings is almost equal by the sowings productivity of the main silage crops, but fodder is characterized by a higher content of protein (Skaliy, 2005; Kolomiets, Matkevich, 2005).

Sowings of corn with white lupine were well-recommended in the experiments carried out under the conditions of the RightBank Forest-Steppe, in Polissya and western regions of Ukraine.

During growing of peas and meadow vetchling, as crops of early sowing, in their combined sowings with corn, their seedlings appear 2-6 days earlier. High-protein plants go before corn by the rates of growth and development, which causes its significant oppression (Matkevich, Smalus \& Kolomiets, 2002; Shchigortsova, 2008). It was found (Renshtein, 2008; Trots, 2008) that the negative effect of peas and meadow vetchling on the growth and development of corn plants was observed a month after seedlings appearing, although there were sufficient supplies of moisture and nutrients in the soil in this period. The main disadvantage of peas and meadow vetchling as the components of corn is that their stems lie down making it difficult for mechanized caring and harvesting. In addition, peas and meadow vetchling already form beans, and their leaves begin to fall off when using them as the components in the mixed sowings at the time of panicle formation in corn (Reinstein, 2008).

According to A. I. Kononenko (1990), it was established that the mixed sowings of corn with soybean exceeded single-crop sowings of corn by 2.12 centners/hectare or by $50 \%$ in the western regions of Ukraine, by 1.99 or $45 \%$ in Polissya, by 1.71 or $44 \%$ in the Forest-Steppe, by 1.13 or 32\% in the Steppe without irrigation, and by 1.95 centners/hectare or $45 \%$ under irrigation taking into account collecting of digestible protein.

Mixed sowings of corn with soybean and corn with annual melilot showed the highest results in yield of herbage and collection of nutrients in the experiments conducted by O. I. Zinchenko and A.O. Sichkar (1999) performed in conditions of Uman Agricultural Academy.

The mixed sowings of corn with borlotti beans provide larger yield of herbage compared to its single-crop sowings in the Forest-Steppe area (Borst \& Park, 1992). In addition, they are also well-gathered by ensilage harvesters.

In Kirovohrad region, researches with the compatible sowings were started in the 1940s of the last century (Ustynchik, 1963). At that time, they sowed compatible sowings of corn with Sudan grass, which were 4.06 and 3.97 t/ha more productive compared to the single-crop sowings of corn and Sudan grass, and by 1.30 and 1.27 t/ha, respectively, by gathering of feed units.

Sharp competition for the factors of life is characteristic in the mutual influence of corn and high-protein crops which is manifested with different intensity during crops vegetation in the mixture (Babich, Merezhko \& Medved, 1989).

So, peas, fodder beans and lupine depress corn in the early stages of the growth and development of the mixed sowings, because these beans are more early ripe and cold-resistant crops than grain varieties. Melilot is characterized by slow growth in the beginning of vegetation, and corn intensively grows and roots in this period. After melilot forms a highly developed root system, it begins to grow rapidly without inhibiting well-developed corn plants. If, we take such crop as soybean for mixed cultivation with corn, then their development will be approximately the same, and the mutual negative effect is insignificant (Sichkar, 2000).

There is an inter-variety competition between the components of the mixture during the growth and development, which is manifested through the peculiarities of the morphostructure and extraction of root systems and above-ground organs. Biological extraction of the plants of some species or even varieties may be harmful or useful for the plants of other species and varieties. So, root extraction of corn is assimilated by bacteria on the roots of legumes, and root extraction of legumes affects the composition of proteins and chlorophyll, and oxidative-reduction processes in corn plants (Lane, 1961).

With regard to the effects of the above-ground organs of plants, some authors believe that the limiting factor in growing of the mixed sowings is the lighting conditions and others-moisture-support and nutrient regime (Skaliy, 2005). Undoubtedly, significant role of a separate factor in a plant life depends on the soil-and-climatic conditions of the growing zone. So, moisture is the primary factor under the arid conditions of the Steppe.

Statements of the researchers concerning the value of water regime in the mixed sowings are quite different in terms of the characteristics of the growing zone, and variety composition of the mixture. It was established that there was better moisture of the upper layers of the soil in compatible crops in dry periods, according to the results of studies by O. I. Zinchenko (1963) and M. F. Lupashku (1989). The reason of this was exudation of moisture by the plants roots that penetrate the lower and more saturated layers. The moisture exudated by the roots of one plant for a long period of time can be a source of water supply for the other plants of a compatible sowing (Zhabykin, 1953). Thus, it was established (Egli, 1990) that moisture spending for the formation of a unit was 3-5\% smaller in the mixed sowings of grain varieties and legumes compared with the single-crop sowings of the same crops.

At the same time, E. I. Guliaiev (1963) and A. I. Livenskyi (1967) point to the deterioration of the water regime in the mixed sowings. Lack of moisture equally negatively affects both on cereals and bean components of mixtures, but the yield of legumes decreases more under such conditions. In turn, vegetative period of mixtures is prolonged under the increase in soil moisture, and, it is reduced by almost three weeks under its decrease (Fedin, 1972). 
A considerable number of researchers note that mixtures of corn with bean components intensively use moisture from the soil in comparison with its single-crop sowings; and both components of the mixed sowings normally grow, develop and form high yields of vegetative mass in years with a sufficient amount of precipitation. However, these components of the mixture compete mutually suppressing each other under the lack of moisture support (Coor, 1989; Bear, 1992).

Corn and soybean are also very demanding to supply the soil with nutritional elements. So, corn not only reduces yields, but also reduces the duration of vegetation under their lack. Soybean is also very demanding to nutrients and takes them out of the soil more than other field crops. Therefore, it is necessary to supply the soil with organic and mineral fertilizers to obtain high yields of corn with soybean (Penchukov, Debely, Derbensky, 1995).

D. M. Prianyshnykov (1962), studying the nutrition of plants in the compatible sowings, pointed out that legumes under a compatible sowing along with grain varieties not only absorb phosphorus from their hard-soluble compounds, but also provided a soil solution that improves the phosphate nutrition of cereals. A. O. Babych (1968), in turn, noted that legume crops almost completely provided themselves with nitrogen due to its fixation from air with legume bacteria, and they also improved nitric nutrition of cereals in the compatible sowings. Thus, corn grown in the compatible sowings with soybean and fodder beans absorbed nitrogen by $14-21 \%$ more compared to its single-crop sowing.

Some researchers (Grookston \& Hill, 1979) prove that high-protein crops in symbiosis with legume bacteria are capable of absorbing molecular nitrogen of the air, and in the result they almost completely support themselves with nitrogen. However, it is necessary that the soil has at least a small amount of easily digestible mineral nitrogen for the formation of tubers at the initial stage of the process of nitrogen fixation.

Numerous observations of the mixed sowings showed (Livensky, 1967; Grookston \& Hill, 1979; Singh, 1979) that the content of nitrate nitrogen in the arable layer increased by $4.6 \mathrm{mg}$, and mobile phosphates-by $5.5 \mathrm{mg} / 100 \mathrm{~g}$ of soil in the mixture of corn with soybean in comparison with its single-crop sowing. This fact can explain the improvement of the conditions for corn growth in the mixed sowings. In addition, high-protein components with legume bacteria enrich the soil with nitrate nitrogen. There is exchange of root exudation between the plants when the roots of corn and soybean contact each other, owing to which corn contains $1.5 \%$ more raw protein compared with its single-crop sowings.

K. A. Timiriaziev (1948) wrote about the assimilation of solar energy by plants the following "... every ray of the sun, not taken by the green surface of the field, meadows or forest is a wealth lost forever... and ones a more experienced descendant will condemn his ancestor for its exhaustion". So, in this regard, the scientist pointed out the advantage of compatible and compacted sowings, which use the conditions of the environment more rationally. Stems and leaves of grain varieties and legumes are placed in different layers, which contribute to the optimum absorption of solar energy (Ross, 1970).

Corn, melilot, fodder beans, soybean, white lupine and fodder peas are light-loving crops. It is usually observed etiolation in these plants under insufficient intensity of the light. The light inhibits this process, and the stronger, the higher its intensity.

Domestic and foreign researchers (Saka, Itos \& Syumiya, 1987) note that the productivity of plants significantly depends on the regularity of the light of the photosynthetic surface. Soybean forms the largest yield at the intensity of the light on the grass stand at least of 1650 lux. The plants are best lighted when the leaves are closed up in the rows at the altitude of 30-40 $\mathrm{cm}$ from the soil surface. If the closure occurred higher-the lower leaves are shaded and there is an early leaf drop as a result of light starvation, which negatively affects the overall productivity of a sowing.

Plant density increases in the mixed sowings of corn with high-protein crops compared with its single-crop sowings, which provides better use of solar energy by $15-20 \%$. In particular, the lighting of the leaves of the upper and middle layers improves under the alternation of high-growth corn plants with low soybean in grain varieties. Soybeans located in the lower layer in agrophytocenoses get $85 \%$ of solar insolation in the early hours, $87 \%$ in the daytime, and $70 \%$ in the evening. However, corn plants in the sowings with rows alternating of the components are better and more evenly lit throughout the day compared to the single-crop sowings (Babich, 1993).

Coefficient of assimilation of PAR (physiologically active radiation) rapidly rises with the increase of the leaf surface, but to a certain extent. Thus, the use coefficient of PAR comes from 0.28 to $0.67 \%$ with the increase of the leaf surface from 10 to 30 thousand $\mathrm{m}^{2} /$ hectare, and it rises only to $0.72 \%$ at 50 thousand $\mathrm{m}^{2} / \mathrm{ha}$. This is due to the fact that the amount of radiation received per area unit of mixed sowings remains constant, regardless of the size of the photosynthetic surface. In the future, there will come a period when the upper layer of leaves will close the lower one and the plant will undergo light starvation. As a result, the lower leaves begin to turn yellow and die (Nichiporovich, Vlasov, 1961).

A similar pattern is followed in relation to the net productivity of photosynthesis. The lack of solar radiation is the reason of this. After this limit, the entire product of photosynthesis is mainly used for the growth of the leaves themselves. Mixed sowings of corn with high-protein components successfully use this feature to increase the yield of herbage (Osadchuk, Shcherbakov \& Nesenko, 1995).

Distribution of solar radiation in the sowings depends on the seed rate and method of sowing, morphostructure and plants habitus, area of the leaf surface and its placement by the layers. Thus, the use of solar energy is improved by a compatible sowing due to the consideration of the peculiarities of leaves placement by layers of the high-protein and cereal components. Therefore, mixtures of fodder crops have a larger leaf surface and higher efficiency of photosynthesis compared with the single-crop sowings (Rakhmetov, 1994; Tokbayev \& Zhurukov, 1998).

One of the most important climatic factors is moisture supply. The gross demand of fodder crops in moisture is uneven in different regions. This is explained by the fact that it depends on the lack of air moisture during the vegetative period. Therefore, the amount of precipitation is significantly affected the growth of plants in the single-crop, and especially, mixed sowings. Thus, corn is significantly lagging behind growth in the mixed sowings in dry years, and there is its strong competition with bean components for the use of soil moisture (Kokokhin, 1999; Yatsenko \& Isaev, 1999). 
Physical evaporation of moisture from the soil surface in the sowings during the vegetative period is conditioned by the type and yield of the crop, level of agrotechnics, fertilizer system, soil-and-climatic conditions, and so on. In this case, the total evaporation, that is physical evaporation from the field surface in the amount of plants transpiration, characterizes the biological water consumption of the sowings (Zadontsev \& Pikush, 1963).

The points of view of the researchers are quite different concerning plants transpiration. Thus, the intensity of plants transpiration on dry soil is much lower compared with the optimal conditions of moisture supply. In turn, A. M. Alpatiev (1957) considered that the plants on dry soils evaporate moisture per area unit of leaves not less than on wet ones. At the same time, the level of evaporation depends on the lack of air humidity and ecological-and-biological features of the crop.

Not all leaves in the plant cover evaporate moisture equally intensely according to L. I. Yevdokymova (1963). Thus, the maximum transpiration level can move from one layer of leaves to another one depending on the phases of the development. The amount of water evaporated by plants is mainly determined by climatic conditions, and much less depends on the intensity of growth. Corn, compared to other crops, is characterized by significant total water consumption under a low transpiration rate. This is due to the fact that this cereal forms much more dry matter than other crops under sufficient moisture supply. Instead, the coefficients of water consumption by corn are very unstable both by zones and by the years of vegetation. Presented features of water consumption indicate that the formation of its yield is in complicated dependence on meteorological conditions and agrotechnical measures of growing (Kokovihin, 1999).

Mixed sowings provide more stable yields that are less dependent on natural conditions. Crops are less susceptible to certain unfavorable environmental factors in mixtures or compacted sowings (Kotovrasov \& Klymenko, 1981; Lupashku, 1989).

The problem of studying the characteristics of the productivity and quality of the mixed sowings depending on the components selection has been interested long enough in Ukraine. Thus, relevant researches have been carried out since the 20 s of the last century in the conditions of Sumy and Chernihiv research stations. A number of studies concerning compatible and sowing crops was done in Vinnytsia, Kyiv, Rivne and other regions (Novak, 1971). The results obtained under different conditions indicate that production of digestible protein significantly increases when corn growing with grain legumes. In this case, the effectiveness of the mixed sowings primarily depends on the soil-and-climatic conditions of the growing zone. The yield of the mixed sowings of corn was higher compared to its single-crop sowings in the vast majority of the experiments and the amount of digestible protein increased by $77-238 \mathrm{~kg} / \mathrm{ha}$. In this case, it was received $68-103 \mathrm{~g}$ of digestible protein compared with 52-60 $\mathrm{g}$ in single-crop sowings per one feed unit.

According to the results of the research of I. V. Gnoievyi (2006), silage of a high quality was received when using the mixed sowings of corn with soybean, which in comparison with corn one contained more: raw protein and fat-by 1.4 times, and digestible protein-by 56\%, which was important for the qualitative balancing of diet rations.

The yield of herbage of the mixture was $52.5 \mathrm{t} / \mathrm{ha}$, including soybean-6.12 t/ha and corn- $46.4 \mathrm{t} / \mathrm{ha}$ according to the data providing by N. O. Bekhtyn (1990). Such results of the researches are confirmed by the observations made in the conditions of the experimental field of Ulyanovsk Agricultural University (Dyrda, 1989), where the mixed sowings of soybean and corn predominated the single-crop sowings of soybean and corn by on the yield of herbage and dry matter by $35-50 \%$.

The results of the researches of different scientists indicate that the maximum yield of herbage was received at the rate of seeding of $75 \%$ of the adopted in a single-crop sowing, which was $50.6 \mathrm{t} / \mathrm{ha}$ under the rotation of four rows of corn and two rows of soybean with a row spacing of $70 \mathrm{~cm}$, with the specific gravity of soybean- $28 \%$. At the same time, the mixed sowings of corn with fodder beans provide the yield of silage-52.0 t/ha, with the output of feed units and digestible protein of 9.2 and $1.2 \mathrm{t} / \mathrm{ha}$, respectively. Similar indicators of a single-crop sowing of corn were $45.0,8.1$ and $0.9 \mathrm{t} / \mathrm{ha}$, respectively. It was also found that the mixed sowings of corn with melilot increased the content of digestible protein to $146.3 \mathrm{~g}$ per one feed unit (Khomych, 1992; Khudenko et. al. 1996).

\section{Conclusion}

Mixed sowings of corn with high-protein components can provide higher yields of herbage and gathering of digestible protein in comparison with a single-crop sowing. At the same time, compatible sowing contributes to the improvement of the growth processes of all crops by optimizing the water and nutrient regimes of the soil, light and temperature conditions and photosynthesis processes by the above-ground mass of the plants.

\section{References}

Allabardin, I. L. (1997). Improving the quality of corn silage. Feed production, 3, $30-31$ (in Rus.).

Alpatyev, A. M. (1957). Issues of water consumption of cultivated plants. Biological basis of irrigated agriculture. Moscow, pp. 361-369 (in Rus.).

Babich, A. A. (1968). Ways to increase vegetable protein in the fodder of the steppe zone of Ukraine. Crop production, selection and forestry. Moscow: Kolos, pp. 47-52 (in Rus.).

Babich, A. A., Merezhko, N. M., \& Medved, S. P. (1989). Features of the cultivation of corn and soybeans in joint crops. The problem of feed protein: Abstracts of the Republican conference. Vinnitsa, pp. 13-14 (in Rus.).

Babich, A. O. (1993). Modern production and use of soy: monograph. Kiev: Harvest, 428 p. (in Ukr.).

Bear, S. P. (1992). Mixed crops of corn and soybeans. Corn, 3, 19-20 (in Rus.).

Bekhtin, N. O. (1990). The possibilities of mechanized harvesting of mixed corn crops with soybeans for silage. Feed and Feeding of Farm Animals, 4, 9 (in Rus.).

Bondarev, V. A. (1996). Receptions to improve the quality of feed. Feed Production, 1, 33-34 (in Rus.). 
Borst H. L., \& Park, G. B. (1992). Experiments with growing corn and soy bean in combination. Ohio Agr. Exp. Sta. Bull, 513 p. (in Engl.).

Coor, R. (1989). Fertilizing soybeans: knowing when where and how means profit. Solutions, V. 33, pp. $35-37$ (in Engl.).

Drozdov, A. V. (1999). Enhancing protein collection due to symbiotic nitrogen. Feed production, 1, 29 (in Rus.).

Dyrda, Ya. F. (1989). Improve technology. Feed Crops, 2, 28 (in Rus.).

Egli, D. B. (1990). Seed water relations and the regulation of the duration of seed growth in soybean. G. exper. Bot, 41, 243-248 (in Engl.).

Evdokimova, L. I. (1963). Features of water consumption for transpiration depending on water availability of a plant. Water regime of plants due to metabolism and productivity. Moscow: Kolos, pp. 177-181 (in Rus.).

Fedin, P. Ye. (1972). The ratio of leguminous crops to soil moisture. Scientific works of the All-Union Research Institute of Leguminous Crops, 4, 127-136 (in Rus.).

Gnoyev, I. V. (2006). Corn Soybean Silage. Proposition, 4, 36-38 (in Ukr.).

Grookston, R. K., \& Hill, D. S. (1979). Grain yields and land equivalent ratios from inter cropping corn and soybeans in Minnesota. Agron, 71, $41-44$ (in Engl.).

Gulyaev, E. I. (1963). Joint maize crops with legumes. Corn, 5, 35-37 (in Rus.).

Khomych, M. (1992). Korn beans in mixed crops. Animal husbandry of Ukraine, 4, $20-21$ (in Ukr.).

Khudenko, M. N., Tsarev, A. P., \& Trunova, V. N. (1996). For green fodder in clean and mixed crops. Corn and Sorghum, 5, 16-17 (in Rus.).

Kokokhin, S. V. (1999). Water consumption of corn in the conditions of southern Steppe at hybridization sites. Journal of Agrarian Science, 9, 78-79 (in Ukr.).

Kokovihin, S. V. (1999). The water-retaining of the maculae in the minds of the holy Steppe on the grounds of the gjbridizatsi. Bulletin of Agricultural Science, 9, 78-79 (in Ukr.).

Kolomiets, L. V., \& Matkevich, V. T. (2005). Technology of sorghum cultivation in clean, mixed and densified crops. Herald Stepan. Kirovograd, pp. 17-18 (in Ukr.).

Kononenko, A. I. (1990). Increasing the productivity of grass mixtures and fodder production. Feed Production, 30, 21-35 (in Rus.).

Kotovrasov, I. P., \& Klymenko, P. D. (1981). Receptions for the intensification of field feed production in the central foreststeppe of Ukraine. Production of feed on irrigated land. Moscow, 26, $42-47$ (in Rus.).

Lane, M. (1961). Conflikt over composition. Soybean Digest, 51, 18-19 (in Engl.).

Livensky, A. I. (1967). Relationship of Corn plants and Soybeans with their Consistent Growth. Bulletin of Agricultural Science, 3, 62-67 (in Ukr.).

Lupashku, M. F. (1989). Ecology and intensification of field feed production. Monograph. Chisinau: Kartya Moldomenyaske, 427 p. (in Rus.).

Matkevich, V. T., Smalus, V. M., \& Kolomiets, L. V. (2002). Mixed crops of fodder crops. Herald Steppe. Kirovograd, pp. $79-$ 89 (in Ukr.).

Nichiporovich, A. A., \& Vlasov, M. P. (1961). About the formation and productivity of the photosynthetic apparatus of different cultivated plants during the vegetative period. Plant Physiology, Moscow: Publishing House of Academy of Sciences of the USSR, 1(8) 19-27 (in Rus.).

Novak, V. G. (1971). Productivity and agrotechnical role of some types of repeated sowing in the conditions of the southern part of the central forest-steppe of the Ukrainian SSR. Abstract of the dissertation of the candidate of agricultural sciences: 06.01.09. Chisinau, 18 p. (in Rus.).

Osadchuk, Yu. V., Shcherbakov, V. Ya., \& Nesenko, P. P. (1995). Striped soybean and maize for grain in the southern Steppe of Ukraine. Bulletin of Agrarian Science, 11, 35-40 (in Rus.).

Penchukov, V. M., Debely, G. A., Derbensky, V. I. (1995). Single-species and mixed crops of leguminous crops. Feed production, 2, 23-28 (in Rus.).

Pryanishnikov, D. M. (1962). On fertilizer fields and crop rotations. Ex. articles. Moskow, 253 p. (in Rus.).

Rakhmetov, D. B. (1994). New high-protein feed crops for the forest-steppe of Ukraine. Bulletin of Agrarian Science, 9, 51 57 (in Rus.).

Reinstein, L. N. (2008). Combined crops of sorghum crops with soybeans for green fodder. Corn and sorghum, 4, 16-19 (in Rus.).

Renshtein, L. K. (2008). From cereal-bean mixes. Livestock of Ukraine, 5, 40-41 (in Ukr.).

Ross, Yu. K. (1970). Structure, organization of crops and cenosis in terms of the best use of the radiant energy of the sun. The most important problems of photosynthesis in plant growing. Moscow: Kolos, pp. $38-50$ (in Rus.).

Saka, N., Itos, G., \& Syumiya, A. (1987). Varietal difference of soybean in the influence of growth and yield under the all light illumination. Res. Bull. Aichi Ken Agr. Res Center Naragute, Aichi, 19, 86-93 (in Engl.).

Shchigortsova, E. A. (2008). Grain-crops-a source of protein consumption. Livestock of Ukraine, 2, 27-29 (in Ukr.).

Sichkar, A. O. (2000). Features of phytoclimate in mixed crops. The collection of scientific works of Uman DAU dedicated to the 100th anniversary of the birth of S. S. Rubyn. Uman, pp. 229-233 (in Ukr.).

Singh, C. M. (1979). Nitrogen acculation in maize inter cropped with grain legumes under varyind levels of nitrogen. Food Farms Agr, 10, 314-315 (in Engl.).

Skaliy, I. M. (2005). Features of formation of productivity of green mass of plants of corn and soybeans in compatible crops depending on the density of standing. Scientific herald of NAU, 84, 189-193 (in Ukr.). 
Skaliy, I. M. (2005). Peculiarities of formation of green mass of corn and soybean plants in compatible crops depending on the density of standing. Abstracts of the scientific conference of the Uman DAU, pp. 58-60 (in Ukr.).

Timiryazev, K. A. (1948). Selected Works. Moscow, 630 p. (in Rus.).

Tokbayev, M. N., Zhurukov, B. Kh. (1998). Symbiotic and photosynthetic activity of vets in sowing in pure form and in a mixture with mustard. Grain farm, 5, 15-16 (in Rus.).

Trots, V. B. (2008). Corn for silage in combination with high-protein crops. Feed production, 7, 18-21 (in Rus.).

Ustynchik, O. K. (1963). Brief summary of the work of the station for 50 years. Collection «50 years of the Kirovograd State Agricultural Research Station». Kyiv, pp. 3-11 (in Ukr.).

Yatsenko, S. Ya., Isaev, A. P. (1999). Peatbrook cultures in feed mixtures. Fodder production, 2, $22-24$ (in Ukr.).

Zadontsev, A. I., Pikush, G. R. (1963). Corn and water. Corn, 9, 37-39 (in Rus.).

Zhabykin, I. P. (1953). Influence of mixed crops on growth, development and productivity of agricultural plants: dissertation of the doctor of agricultural sciences: 06.01.09. USHA. Kiev, pp. 8-15 (in Rus.).

Zinchenko, A. I. (1977). Methods of intensive fodder production. Monograph. Uman, 171 p. (in Ukr.).

Zinchenko, O. I., Sichkar, A. O. (1999). Stern wedge of the southern forest-steppe of Ukraine (some aspects of theory and practice). Bulletin of Agrarian Science. Special Issue (September), pp. 42-45 (in Ukr.).

Citation: Poltoretskyi, S., Prykhodko, V., Poltoretska, N., Prokopenko, E., Demydas, H. (2019). Agro-ecological and biological aspects of the components selection for mixed sowings of forage crops. Ukrainian Journal of Ecology, 9(3), 31-36.

(cc) EY This work is licensed under a Creative Commons Attribution 4.0. License 